\title{
“THE BODY DOES MATTER": WOMEN AS EMBODIED SOCIAL SUBJECTS IN ANGELA CARTER'S NIGHTS AT THE CIRCUS
}

ABSTRACT. Postmodernism posed a crucial ontological challenge to reality, questioning what constitutes the real world, simultaneously interrogating the horizon of representation of this unstable reality in fiction. Feminism on the other hand equipped us with critical tools for interpreting the reality of being in the world in a gendered body, as well as with a conceptual apparatus for interpreting the manifold institutional and private oppressions of women's bodies that play out in women's daily lives and in the discourses that shape them, literary discourse being one of them. This paper argues that Angela Carter's 1984 novel Nights at the Circus, which is widely held as a postfeminist text due to its narrative commitment to transcending gender binaries, essentially uses the strategies of postmodern storytelling and characterization in order to explore women's embodied potentialities of agency i.e. their construction of subjectivity through body. We will argue that the hybrid magic realist narrative constructs Fevvers' body as a titillating postmodern performance, ontologically illusive and elusive, yet it grounds that same body in various socially effected predicaments and experiences that serve to show that even in the midst of a play of signifiers, in Patricia Waugh's words, "the body does matter, at least to what has been the dominant perspective within British female fiction" (Waugh, 2006, p. 196). In other words, it may be argued that Carter's novel is invested in traditional second-wave feminist politics to the extent that it shows that a woman's body is an indispensable medium of being in the world with material consequences that bear on the formation of her subjectivity and possibility of

tatjana.milosavljevic@educons.edu.rs

This paper was submitted on July 14, 2016 and accepted for publication at the meeting of the Editorial Board held on September 29, 2016. 
agency, and through which she acts out her relationships to others and is acted upon.

KEYWORDS: Angela Carter, second-wave feminism, postfeminism, body, materiality.

\section{INTRODUCTION}

Helen Stoddart remarks that Nights at the Circus was unanimously recognized upon publication as a "huge shift in style and emphasis in Carter's writing" (2007, p. 46) and that its larger-than-life feminist heroine, embodiment of the New Woman at the turn of the 20th century, is representative of Carter's later fiction, in contrast to the victimized female characters of the earlier novels, such as The Magic Toyshop (1967) and Love (1971). In Nights at the Circus the parentless and dubiously winged Cockney foundling who goes by the name of Sophie Fevvers and works as a popular circus act claims to have been hatched from an egg, inciting the curiosity of a skeptical American journalist who comes to London to interview her. Fevvers delivers to the bewildered journalist a postmodern tale of a self-fashioned subject freed from the constraints of paternal origin, and incidentally, of the determinism of class and gender. At the same time, Fevvers' leviathan bird-woman's body, her radical agency, and attempts at individualism are all limited throughout the narrative by the constraints of her female gender and the lowest rung of society in which she is brought up by her adoptive mother, a kind prostitute named Lizzie working under the patronage of the resourceful yet good-natured madame, Ma Nelson. The gendered, i.e. feminized nature of poverty is central to the narrative's feminist political bent, as female characters keep appearing as body-objects of exploitative sexual labour or marital violence, while male characters are summoned as perverse aristocrats, middle-class Machiavellians or brutish lower-class alphas.

Fevvers' dubious account of her extraordinary life and career beginning as an adolescent fixture in a brothel (posing as Winged Victory), followed by a stint as a slave in the Museum of Women Monsters (posing as Angel of Death) and ending in her rise to stardom as a circus performer is interspersed with accounts of Fevvers' fantastical flights from violent men, and with embedded narratives of other bizarre female characters with woeful chronicles of betrayal, oppression, and maltreatment. In its glorification of the 
female freak, Nights is an exemplary postmodern work for Linda Hutcheon who claims that the ex-centric, the off-center, especially the female freak is a metaphor for a pluralized world where there are no centres, only ex-centricity (Hutcheon, 1988). Yet, both the splintering episodes and the main narrative thread that charts Fevvers's fantastical adventures are accompanied by Lizzie's sobering socialist commentary on the imbalance of gender relations and the injustice inflicted on the lumpenproletariat, especially on its female half.

Reflecting on the continuity of female writing in Britain from pre-feminism, through first-, second-, and third-wave feminism, down to the post-feminist moment, Patricia Waugh cites the protestations of Germaine Greer in her 2000 book, The Whole Woman, about what Greer perceives as lamentable post-feminist embrace with the postmodern artifice and performativity that she finds are not conducive to the goals of female liberation from the continuing reality of oppression and inequality (Waugh, 2006, p. 188). Pivotal battles are yet to be won, while Greer feels that second-wave feminists have given up their serious commitment to political liberation in favour of the seductive, but ultimately shallow lure of postmodern appetite for self-fashioning, where women's appearances matter more than the substance of their lived experiences. Waugh, however, sees no need for such pessimism and traces a continuing feminist thread in British women's writing, naming Angela Carter as one of the authors who has managed to employ metafictionality, illusionism, ironic parody, and deconstruction of gender binaries while sustaining a serious engagement with women's material conditions of existence (Waugh, 2006, p. 192).

The largest body of criticism of Angela Carter's novel Nights at the Circus celebrates the carnivalesque energy and the extravagant body performances of its heroine Sophie Fevvers ${ }^{2}$. These readings are closely aligned with Judith Butler's poststructuralist theory of gender as performance, and the typically postmodern approach to body as immaterial and non-biological, as a disembodied discoursive practice, that is, an effect of a play of signifiers that produce the gendered effect through playing (Butler 1990, 1993, 2004). The postmodernism of Carter's novel, evidenced in its pastiche temporality, parodic historiography, and carnivalesque exuberance, as well as in

2 See O'Brien (2006) on carnivalesque bodies and freakishness in the novel. 
its conception of the body as performance, have all contributed to interpretations of Angela Carter as averse to the Realpolitik of second-wave feminism and have aligned her with Butlerian postmodern feminism and post-feminism ${ }^{3}$. However, it is possible to elucidate the staunch second-wave feminist aspirations of Carter's text by juxtaposing the physical experiences of Fevvers and other female characters with the outlandish postmodern escape routes Fevvers must resort to whenever she is threatened with serious bodily harm. The first such scene is her flight from the deranged Rosencreutz who buys her in order to brutally sacrifice her through proxy rape with a phallic dagger, while later Fevvers magically slips through the hands of another perverse aristocrat, the Russian Grand Duke who wishes to turn her curious body into an artifact in his morbid toy collection, symbolizing the ultimate objectification of the female body. We would argue that despite casting Fevvers as a mythical performer par excellence, and employing the textual pleasures of postmodern aesthetics in the description of the fabulous picaresque adventures of the heroine, the underlying morale of these scenes is a recognition that oppression and violence must not be viewed as effects of signification, but as lived traumas that cannot be escaped unless you are a winged giantess with the ability to fly out the window of your attacker's mansion or to magically board toy trains back to safety, as Fevvers does.

\section{EMBODIED PARADOX}

Nights at the Circus presents us with the irresistible paradox of Sophie Fevvers, a monumental mythical beauty with wings who speaks fluid Cockney. Even her bizarre name carries a class marker

3 Postfeminism is a postmodern strand of the feminist movement that builds on the historical struggle for female empowerment but also transcends its binary logic (pivotal to second and third-wave feminism) to theorize a society freed from the discrete gender roles emanating from the "male" and "female" constructions of identity and the corresponding imbalance of power in favour of the male. Thus, The Routledge Companion to Feminism and Postfeminism (1999), edited by Carter's notable biographer and critic Sarah Gamble, remarks that Carter's (typically postfeminist) sex-positive attitude expressed in, for instance, The Sadean Woman (1978), generated much denunciation from high-profile feminist scholars such as Andrea Dworkin for the text's endorsement of pornography, which is widely regarded by second-wave feminism as demeaning and dehumanizing to women (p. 167). 
- the prostitutes at the Battersea brothel who supposedly find baby Fevvers hatched from an egg at their doorstep notice she looks like she is about to sprout feathers, which these working-class London girls pronounce as "fevvers". The familiar images and voices of Dickensian London are thus defamiliarized with the disruptive hatching of a feathered baby, setting the tone of the novel for what Brian McHale calls "a naturalized heterotopia" in postmodern fiction, that is, magic realism ${ }^{4}$ with the emphasis on the realism (1987, p. 53). The novel opens with Fevvers' idiosyncratic South London heartiness: “ 'Lor' love you, sir!' Fevvers sang out in a voice that clanged like dustbin lids. 'As to my place of birth, why, I first saw light of day right here in smoky old London, didn't I! Not billed the 'Cockney Venus', for nothing, sir" (Carter, 2012) lect in which Fevvers tells Walser her incredulous life account contributes to the intertextual parody (the text alludes to the ancient Greek myth of Leda and the Swan) and partakes in her seductive ambivalence and indecipherability: she appears at once down-to-earth and larger than life, familiar and alien, feminine and grotesque, angel and freak, vulgar and celestial, contemporary and mythical, working-class and other-worldly.

The historiographic account of this wondrous winged aerialist hailed from the working-class South London district of Battersea is initially filtered through the lens of one man's seemingly discerning look: she is being interviewed after one of her circus performances by a young American journalist who is eager to learn whether she was truly born with wings or if she were a fraud. Walser's unmistakable class gaze on Fevvers' body, which is also the gaze of patriarchy, is summarized in the following passage:

"In his red-plush press box, watching her through his opera-glasses, he thought of dancers he had seen in Bangkok, presenting with their plumed, gilded, mirrored surfaces and angular, hieratic movements, infinitely more persuasive illusions of the airy creation than this over-literal winged barmaid before him. 'She tries too damn' hard,' he scribbled on his pad.” (Carter, 2012)

Fevvers's body reminds Walser of other lower class women in the entertainment profession whose performance he had enjoyed as a privileged American male tourist, "dancers he had seen in Bang-

For situating the novel within the genre of magic realism, see Henitiuk (2003).

In the paper, an electronic 2012 Kindle edition of the book is referred to, hence pagination is not indicated. 
kok". Yet, the reader, together with Walser, is to be startled out of this passivizing image of an exotic female acrobat, as Fevvers' acrobatic performance spills out from the circus stage into the manipulative narrative she weaves. Fevvers' account of coming into the world - having been hatched from an egg - is a crucial origin myth for this heroine as it enables Fevvers to escape the structuring paradigms of female body created by patriarchy. The denaturalization of Fevvers' body in her origin myth divests Fevvers of the "natural" lineage that is subject to social hierarchization and Fevvers' parentless state opens up the possibility of self-invention in an otherwise rigidly structured English society of the fin de siècle.

Through Walser's condescending gaze, Fevvers is strategically introduced by Carter as a typically silent female subject of literary representation, especially in the case of lower class women, which makes the subsequent defamiliarization of her character even more striking. Michael notices how the narrative is soon hijacked from Walser by Fevvers and other female characters, "telling their stories-histories in long monologues that often include vivid dialogue" (1994, p. 495). The appropriation of language and voice by these women parallels their seizing of control over their representation in male-dominated sexist discourses on prostitution and women working in entertainment. Moreover, Carter's deconstruction of the literary tradition of male authority in story-telling is expertly delivered through a subtle shift of focalization from Walser to the female characters which parallels the women's reclamation of their means of sustenance and their bodies as a source of profit, especially in the case of Fevvers, Lizzie, Mignon, and Princess of Abyssinia. However, Fevvers' Cockney-accented life story subverts the classical plot of a bourgeois Bildungsroman with which it flirts (Christianidis, 2012), and it is not the upward mobility that Fevvers is after, nor the fulfilment of some social destiny, but physical and financial independence, as well as a voice with which to narrate her own history. Hence, the inscription of Fevvers' body into the means of production is presented by Carter through a postmodern fabulist narrative that problematizes the very foundations of the system in which gender and class relations are rooted.

So, what could a bird-woman's body mean ${ }^{6}$ Semioticization of Fevvers' body is achieved through the self-parodic images of the

6 For an ecofeminist perspective on woman-animal transcorporeal imaginings in the novel, see Yang (2016). 
unnatural spectacle of her winged form that is culturally threatening because it bends the acquired notions of the possible and the knowable: "marvellous, indeed, but a marvellous monster, an exemplary being denied the human privilege of flesh and blood, always the object of the observer, never the subject of sympathy, an alien creature forever estranged" (Carter, 2012). This quote may be applied to the female condition under the male gaze as conceived by second-wave feminism that ascribes the antagonistic attributes of naturalness and monstrosity to the woman's body, symbolized by Fevvers' grotesque form. Fevvers' polyvalent body thus parodies the images of femininity by taking them to the extreme (Kérchy, 2004, p. 99), and thwarts the power of the male gaze to discern the female body and to contain and control the discourses that construct it. It is no wonder, then, that this socially transgressive body is pursued by oppressors who seek to capture, imprison and exploit her in underworld commercial spaces such as the Museum of Women Monsters.

\section{EMBODIED LABOUR}

Fevvers' paradoxically seductive and monstrous form is primarily an allegory of the male dread of the womb and of the fear of the abject maternal body diagnosed in psychoanalysis, as noticed by numerous feminist critics, but it also addresses the issue of the woman's place in the economic circuit, as an instrument of labour. Fevvers' uneasily won agency in the novel consists first and foremost in her learning to seize control of the uses of her body and use to her own advantage the matrix of patriarchal economy that anchors the exploitation of women. Writing on the resolving of the long-running tension between the widely criticized apoliticism of postmodernism and the politically engaged Marxist feminism in the novel, Michael remarks that "in order to both analyze the status of women and of existing relationships between women and men within Western culture and, more radically, propose possible avenues for change, Carter pits a Marxist feminist realism against postmodern forms of tall tales or autobiographies, inverted norms, carnivalization, and fantasy" (p. 493). Furthermore, Michael observes that the complexity of the novel's feminist arguments is constructed by bringing into dialogue the materialist analysis of the woman's position in the British class spaces with a subversive 
(postmodern) utopian feminism. While Fevvers' body-text stretches the boundaries of the possible, both Lizzie's personality and body are firmly grounded in the familiar, material socio-historical circumstances of her age, in the tradition of the realist writing. Hence, in contrast to the fabled depiction of Fevvers, the narrator casts Lizzie in the commonplace and familiar images of squalor and working-class female defiance:

"Lizzie was a tiny, wizened, gnome-like apparition who might have been any age between thirty and fifty; snapping, black eyes, sallow skin, an incipient moustache on the upper lip and a close-cropped frizzle of tri-coloured hair - bright grey at the roots, stark grey in between, burnt with henna at the tips. The shoulders of her skimpy, decent, black dress were white with dandruff. She had a brisk air of bristle, like a terrier bitch. There was ex-whore written all over her" (Carter, 2012).

The highly compartmentalized social spaces that these two principal female narrators inhabit in the novel illustrate the position of the working-class woman as a subject. The first of these spaces is the brothel, which is the most explicit rendition of the sexual division of labour and gendered formation of subjectivities. It is a space in which both the employees and their benevolent employer Ma Nelson are women, and where no brutal capitalist exploitation seems to pass. Yet, the uses of the female body, as an instrument of labour for these women and the commodity to be bought and sold on the market, takes place under the twofold regime of power: the patriarchal gaze and the class gaze. The alienation of a prostitute's labour is highlighted in Lizzie's belief that what these women are selling is not sex, but its illusory substitute, or "simulacra", as Lizzie explains (Carter, 2012). Lizzie's sobering materialist analysis of the goings-on in Ma Nelson's brothel serves to re-humanize the depersonalized body of the prostitute, as she tells Walser these women are committed "suffragists" invested in various forms of intellectual self-improvement outside their working hours, helping them to embark on new careers once Ma Nelson's puritanical brother closes the brothel. Lizzie is particularly careful to demystify romanticized conceptions of prostitution and emphasize the state of economic destitution as the driving force behind their labour, which is a criticism of the dominant Victorian-era discourse of the sexually incontinent woman that allegedly turns to prostitution to satiate her appetite: 
"But what followed after they put away their books was only poor girls earning a living, for, though some of the customers would swear that whores do it for pleasure, that is only to ease their own consciences, so that they will feel less foolish when they fork out hard cash for pleasure that has no real existence unless given freely oh, indeed! We knew we only sold the simulacra. No woman would turn her belly to the trade unless pricked by economic necessity, sir" (Carter, 2012).

The next space in which Fevvers finds herself is the bondage of the dreadful Madam Schreck's Museum of Women Monsters, in which women with various physical anomalies and in dire straits are displayed or sexually exploited by the male customers with a more unusual taste. Apart from Fevvers, the bizarre museum counts, among others, a midget called the Wiltshire Wonder, a hermaphrodite Albert/Albertina, the Sleeping Beauty, whose tenuous body perishes in a state of perpetual sleep, and Cobwebs, who has another pair of eyes in the place of nipples. The very title of this establishment and the freakish bodily anomalies of its residents take further the topic of the abject female body, which is feared and desired by men at the same time. The gothic space ${ }^{7}$ of the Abyss, as the museum is called by its residents is a metaphor of an underworld hell, but it may also be interpreted as a class space, denoting the lowest rung of the social ladder, i.e. the underclass. This interpretation is supported by the destitute position of its female slaves, such as Fevvers' urgent need of money which drives her to the museum's doors, or the case of the Wiltshire Wonder, who finds herself there after being sexually abused by a group of seven midgets and then abandoned by them penniless. Once again, it is the coeval forces of patriarchy and economic forces that construct an oppressive space in which vulnerable women are preyed upon for their bodies and lured into a state of bondage and dependency.

The question of class also arises in the contrasting social positions between the museum's showpieces and its clientele. We learn from Fevvers that the visitors of the museum mostly comprise affluent upper-class men, while the deluded Mr Rosencreutz who buys Fevvers from Madam Schreck with the intention of sacrificing

7 Munford's paper "The Desecration of the Temple; or Sexuality as Terrorism? Angela Carter's (Post)feminist Gothic Heroines" (1997) explores the relationship of Nights at the Circus, among other works, to the "female Gothic" and the narratives of "victim feminism". 
her to achieve eternal youth is revealed to be an esteemed member of the parliament and an aristocrat who only the day before gave "the most impressive speech in the House on the subject of Votes for Women. Which he is against." (Carter, 2012). The museum of women monsters is thus, paradoxically, at once an all-female realm and a space tightly structured by the patriarchal gaze ${ }^{8}$. It is simultaneously a hierarchized class space as it is economically maintained and controlled by men from the upper echelons of society who use the museum to "slake their fantastical desire" (Carter, 2012) as the Wiltshire Wonder remarks, upon its wretched inhabitants, or to buy and dispose of their commodified bodies as they please, which is the intention of the deranged Rosencreuntz. Particularly memorable image that closes this chapter as a post-commentary on the subjects of gender and class that it explores is Fevvers' romanticized vision of feminized urban poverty in the early winter morning. Poverty strikes multitudes of Victorian Londoners, but the slice of humanity on the streets that Fevvers focuses on is that of the down-trodden women and their barefoot children who are running after a coal cart trying to obtain any shard that falls off:

"At the end of Whitehall, along the wide road, past the Mother of Parliaments, there came at a brisk trot a coal cart pulled by clattering, jingling drays, and, behind, an impromptu procession of women of the poorest class, without coats or wraps, in cotton pinafores, in draggled underskirts, worn carpet slippers on their bare feet, and there were shoeless little children too, running, scrambling after the carts, the girls and women with their pinafores outstretched to catch

8 This space recalls Roland Barthes' analysis of the Elle magazine article in his ground-breaking structuralist work Mythologies. Barthes reads the semiotics of the article in this popular female magazine on successful French women as fully controlled by the omniscient yet invisible gaze of the male god: "Where then is man in this family picture? [...] Man is never inside, femininity is pure, free, powerful; but man is everywhere around, he presses on all sides, he makes everything exist; he is in all eternity the creative absence, that of the Racinian deity: the feminine world of Elle, a world without men, but entirely constituted by the gaze of man, is very exactly that of the gynaeceum [...]" (Barthes, 1972, 51). Another such space in the novel is the all-female panopticon prison in Transbalaika in which the inmates and the guards, deprived of the freedom to use language, must resort to the resources of their own body, such as menstrual blood, in order to communicate. Both the inmates and the builder of the panopticon prison are women who murdered their husbands, mostly in self-defense, which makes the women's prison another space that is structured and policed by patriarchal ideology. 
every little fragment of coal that might bounce out. 'Oh, my lovely London!' said Fevvers. 'The shining city! The new Jerusalem!'” (Carter, 2012).

It is particularly evocative that the scene takes place in the vicinity of the Houses of Parliament, ironically dubbed "Mother of Parliaments", although it represents the centre of state power entirely dominated by affluent, privileged men who get to decide on the faith of the passing dejected women and children, emblematic in Rosencreuntz's parliament speech against the women's suffrage.

\section{EMBODIED SUBJECTS}

Delivering herself from Madam Schreck's and Mr Rosencreutz's murderous grip, Fevvers joins a circus as its most prized act. The circus with which she travels on the Grand Imperial Tour of Russia finally grants Fevvers the long-coveted sovereignty and financial independence, and even if not utopian, this space of potentiality is the culmination of the novel's construction of theatrical settings that explode the difference between the simulacra and reality. The circus's carnivalesque and de-centred atmosphere is heightened by the character of its boisterous owner Colonel Kearney who gives up his better judgement in favour of a fortune-telling pig named Sybil. The circus is, however, an ambivalent space for women, since Carter draws a contrast once more between Fevvers' bodily autonomy and the lack of bodily autonomy of other female circus acts. A number of males, such as the Strong Man and Monsieur Lamarck, Mignon's abusive alcoholic husband in charge of training monkeys, rule tyrannically over the circus women. Fevvers, as a privileged star of the show, remains untouchable to this phase in her career, a spectacle to be observed and not physically used by men, but the circus presents us with Mignon, a heavily abused girl-child with several layers of bruises on her diminutive body, inflicted by her husband, the last of her abusive guardians. A disruptive event at the circus when a tigress attacks Mignon, and Walser saves her, reconfigures all alliances and sets in motion vital transfigurations of the novel's gender roles. Walser's graceful act gives a new lease of life to Mignon which she uses to construct self-confidence and agency for the first time in her life and builds a loving union with 
the Princess of Abyssinia, while the Strong Man, Mignon's former brutish lover, grows tongue-twisted and awe-struck by the beauty of Mignon's budding lesbian romance. Thus emasculated Strong Man exchanges his imbecilic physical prowess for moral integrity, while Walser undergoes his own personal transformation by renouncing all social power and becoming a clown.

This crucial episode dramatizes the novel's insistence that the body one inhabits not only inflects one's subjectivity, but goes further in suggesting that the body is both constructive and deconstructive of subjectivity. This is articulated by Buffo the clown who philosophizes: "take away my make-up and underneath is merely non-Buffo. An absence. A vacancy" (Carter, 2012). Walser's adoption of clown identity (or rather, non-identity, as testified by Buffo) is thus the most radical bodily experience of a male character in the novel. Johnson remarks that "as a clown, Walser becomes the object of art, a spectacle, and like Fevvers, he experiences the terror of body as text" $(1995$, p. 67), that is, he learns what it means to live in a body socially marked as Other and treated as non-identity. With non-identity come manifold abuses of the body perceived as sub-human, and Walser "discovers what it is like to have his body persecuted, mutilated, stared at" (p. 67). When Walser subsequently loses his memory and language, falling prey to the influence of a tribal shaman who finds him disoriented and rummaging through the Siberian wilderness, he undergoes the final necessary step on his path toward a romantic union with Fevvers based on mutuality and equality. The loss of language is the ultimate loss of the self, and it tests the limits and potentialities of a more equitable future for both genders that becomes imaginable once Walser is stripped of his masculine authority over language and representation. His look of vulnerability and weakness when he is discovered by Fevvers makes her contemplate marriage for the first time and excitedly chirm to Lizzie: "Oh, but Liz, think of his malleable look. As if a girl could mould him any way she wanted... I will transform him... I'll sit on him, I'll hatch him out, I'll make a new man of him" (Carter, 2012) The more experienced and world-weary Lizzie, however, warns that Fevvers's plan will not run as smoothly as she predicts, since once Walser recovers language and memory of his past social power, he will try to recover his authority over her life narrative, as evidenced in his final reference to Fevvers as Mrs Sophie Walser, his wife. Yet, although Walser's metamorphosis may not be complete, it is irreversible and 
gives Fevvers leverage. Walser is dismayed to learn that he has been both instrumentalized and duped by Fevvers, at the same time when she triumphantly makes love to him in the "girl-on-top" position (the only one available for a woman with wings). Walser is informed that he has unknowingly been made the instrument of Lizzie's communist activism, i.e. that they used him to smuggle "news of the struggle in Russia to comrades in exile" (Carter, 2012) in his diplomatic bag, originally intended to provide Walser's editors with the story of Fevvers' (in)authenticity as a bird-woman. In this way, Walser's original enterprise to understand, interpret, and represent Fevvers, to fix her body in his language, is turned on its head. The novel ends in Fevvers' famed triumphant laughter at the thought that she duped Walser into believing she was a virgin, yet Walser is now able to laugh along with her, as he has seemingly surrendered his claims of masculine authority to the power of her feminine trickery. John Sears reads the novel as an "entertaining rebuff to postmodern and poststructuralist theories, such as Derrida, Foucault, Debord, and Baudrillard" (it is safe to add Butler to this list), since he finds their anti-essentialist writings are implicitly satirized throughout the text. But Sears reads the ending as lacking in this respect, since the novel "tends to fall back into a kind of essentialism of its own, explicit in the text's neatly rounded closure" (Sears, 1993, p. 246). I would argue that these remnants of essentialist reasoning in Nights bridge the gap between Carter as a second-wave feminist and a post-feminist author, in repeated narrative acts that re-embody subjectivity, even as they play with poststructuralist theories and rely on postmodern bravado for the aesthetic effect, in order to foreground the continuing call for the body autonomy and sexual and economic self-determination of women.

CONCLUSION The novel Nights at the Circus may be read as a fictionalized study of Britain's evolving gender and class relations which perhaps stands as the purest expression of Carter's feminist and socialist convictions. The tension of the double-frame politics of the novel, at once postmodern and feminist, exposes and dismantles the patriarchal architecture at the base of the British class system, rendering the working-class woman as both the victim and the revolutionary. Carter's female protagonists of Nights at the Circus may be said to originate in the confines of the British class system rooted in patriarchy, yet they actively seek and ultimately occupy an embodied 
subject position outside the dominant ideological circuit, by seizing new and inventive strategies of agency. The main character Sophie Fevvers in particular stands for feminist heroines and harbingers of the $20^{\text {th }}$ century tectonic shifts in Britain's cultural life characterized by a profound deconstruction of its burdensome patriarchal and imperialist heritage that is particularly exploitative toward the body of "the working girl". Even the circus, a carnivalesque space in the Bakhtinian sense that offers to Fevvers abundant freedom and economic independence is not a safe haven for the outcasts, but markedly a part of the exploitative entertainment industry that rests on the abuse of a string of female circus acts less fortunate or less profitable than Fevvers. At long last, the paradoxical Cockney Venus triumphs if only temporarily over the omnipresent patriarchal oppression (to which several female characters act as handmaids) and subjugates her love interest Walser to the authority of her enigmatic body, ushering in an era of female empowerment at the turn of the $20^{\text {th }}$ century, as well as of shifting economic and cultural paradigms that will raise the social status of popular entertainers such as herself. In its oscillation between postmodern illusionism and the interrogation of women's social bodies, the novel performs the exact opposite of postmodernism's method of choice - constructing a reality effect that is subsequently radically destabilized, i.e. deconstructed. Instead, Angela Carter's magic realist narrative is a construction that becomes deconstructed to the level of material, embodied experiences, which aligns the novel with the agenda of traditional feminist politics, as much as with post-feminism with which it is commonly associated.

REFERENCES

Barthes, R. (1972). Mythologies (A. Lavers, Trans.). New York: The Noonday Press.

Butler, J. (1990). Gender Trouble: Feminism and the Subversion of Identity. New York: Routledge.

Butler, J. (1993). Bodies that Matter: On the Discursive Limits of "Sex". New York: Routledge.

Butler, J. (2004). Undoing Gender. New York: Routledge.

Carter, A. (1967). The Magic Toyshop. London: Heinemann.

Carter, A. (1971). Love. London: Hart-Davis. 
Carter, A. (2012). Nights at the Circus. Kindle ed., Vintage digital. (Original work published 1984).

Christinidis, G. (2012). Radical Transformation: Angela Carter's Adaptation of the Bildungsroman. Textual Practice, 26(3), 467-487.

Gamble, S. (1999). The Routledge Companion to Feminism and Postfeminism. New York: Routledge.

Henitiuk, V. (2003). Step Into My Parlour: Magic Realism and the Creation of a Feminist Space. Canadian Review of Comparative Literature/Revue Canadienne de Littérature Comparée, 30 (2), 410-427.

Hutcheon, L. (1988). A Poetics of Postmodernism: History, Theory, Fiction. New York: Routledge.

Johnson, R. M. (1995). Postmodern Hero in Angela Carter's Fiction. Unpublished manuscript, University of Montana. Retrieved from http://scholarworks. umt.edu/cgi/viewcontent.cgi?article $=4285 \&$ context=etd.

Kérchy, A. (2004). Corporeal and Textual Performance as Ironic Confidence Trick in Angela Carter's Nights at the Circus. The AnaChronisT, 10, 97-124. Retrieved from http://seas3.elte.hu/anachronist/2004Kerchy.pdf.

McHale, B. (1987). The Postmodern Fiction. London: Routledge.

Michael, M.C. (1994). Angela Carter's Nights at the Circus: An Engaged Feminism via Subversive Postmodern Strategies. Contemporary Literature, 35(3), 492-521.

Munford, R. (2007). "The Desecration of the Temple"; or, "Sexuality as Terrorism"? Angela Carter's (Post)feminist Gothic Heroine. Gothic Studies, 9(2), 58-70.

O’Brien, W. (2006). Feminine Freakishness: Carnivalesque Bodies in Angela Carter's Nights at the Circus. Genders, 44, 1-20.

Sears, J. (1993). Gothic Times: Feminism and Postmodernism in the Novels of Angela Carter. Unpublished Manuscript. University of Sheffield, Sheffield, United Kingdom.

Stoddart, H. (2007). Angela Carter's Nights at the Circus: A Routledge Study Guide. London: Routledge.

Waugh, P. (2006). The Woman Writer and the Continuities of Feminism. In: James F. English (Ed.), A Concise Companion to Contemporary British Fiction (177206). Oxford: Blackwell Publishing.

Yang, K.J. (2016). Angels and Feathers: Transcorporeal Morphing in Angela Carter's Nights at the Circus. Critique: Studies in Contemporary Fiction, 57 (5), 502511. 
ТАТЈАНА Б. МИЛОСАВљЕВИЋ

УНИВЕРЗИТЕТ EDUCONS

СРЕМСКА КАМЕНИЦА

РЕЗИМЕ

„ТЕЛО ЈЕСТЕ БИТНО“: ЖЕНЕ КАО ОТЕЛОВЉЕНИ ДРУШТВЕНИ СУБЈЕКТИ У РОМАНУ НОЋИ У ЦИРКУСУ АНЪЕЛЕ КАРТЕР

Постмодернизам је поставио неке од кључних онтолошких изазова појму стварности, истовремено испитујући хоризонте могућности да се та нестабилна стварност представи у прози. Феминизам је, с друге стране, изнедрио концептуални апарат за тумачење стварности тела, тј. ठивствовања у телу које је обележено родом, као и за анализу стварности у којој не јењавају многоструки институционализовани и приватни видови тлачења женског тела који се испољавају како у свакодневном животу жене тако и у дискурсима који обликују род, а у које се убраја и књижевни дискурс. Овај рад се ठави романом Анђеле Картер Ноћи у циркусу (Angela Carter, Nights at the Circus), који је општеприхваћен као постфеминистички текст због настојања ликова да превазиђу бинарне дуалности рода, при чему је циљ рада да покаже како су у тексту употрељљене приповедачке стратегије постмодернизма да ठи се испитали потенцијали отеловљеног деловања жене, тачније, на који начин женски ликови у роману граде субјективитет кроз своја тела. Може се рећи да хибридни магични реализам наратива конструише тело јунакиње Софи Феверс као заводљиву постмодерну представу, онтолошки неухватљиву и илузорну, али истовремено утемељује то исто тело у разним друштвеним контекстима и материјалним искуствима тела која су доказ да, према речима Патрише Bo (Patricia Waugh) „тело јесие британске женске прозе“9 (Waugh, 2006, стр. 196). Другим речима, ово дело Анђеле Картер можемо тумачити као политички ангажовано у традицији феминизма другог таласа, уколико узмемо у обзир да је једна од централних тема романа концептуализација женског тела као неизоставног медијума бивствовања у свету, са материјалним последицама које су чиниоци у конструкцији субјективитета жене и њених могућности за делање. Стога, тело у роману је основни инструмент којим женски ликови успостављају разноврсне односе моћи с другим субјектима.

9 Превод аутора рада. 
КључнЕ РЕчи: Анђела Картер, феминизам другог таласа, постфеминизам, тело, материјалност.

Овај чланак је објављен и дистрибуира се под лиценцом Creative Commons Ауторство-Некомерцијално Међународна 4.0 (CC BY-NC 4.0

https://creativecommons.org/licenses/by-nc/4.0/).

This paper is published and distributed under the terms and conditions of the Creative Commons Attribution-NonCommercial International 4.0 licence (CC BY-NC 4.0 | https://creativecommons.org/licenses/by-nc/4.0/). 